\title{
PENGARUH QUALITY OF WORK LIFE (QWL) DAN REWARD TERHADAP ORGANIZATIONAL CITIZENSHIP BEHAVIOR (OCB) PADA GURU SEKOLAH DASAR NEGERI (SDN) DI BABELAN BEKASI
}

\author{
Marhamah $^{1}$
}

\begin{abstract}
The objective of this research is to obtain information about the effect of quality of work life (QWL) and reward on teachers organizational citizenship behavior (OCB). This research used quantitative approach. The research was conducted to all of state elementary schools teachers in the district of Babelan Bekasi by using a survey method with path analysis applied in testing hypothesis. Population in this research were 129 teachers of Estate Elementary School.The research conclude: (1) There is a direct positive effect of quality of work life (QWL) on organizational citizenship behavior (OCB). (2) There is a direct positive effect of reward on organizational citizenship behavior (OCB). (3) There is a direct positive effect of quality of work life (QWL) on reward. Therefore to enhance teachers organizational citizenship behavior can be carried out by quality of work life (QWL) and reward.
\end{abstract}

Keywords: quality of work life (QWL), reward and organizational citizenship behavior (OCB)

\section{PENDAHULUAN}

Sekolah sebagai salah satu lembaga pendidikan yang diharapkan mampu menghasilkan sumber daya berkualitas, perlu didukung oleh guru yang berdedikasi tinggi, kreatif dan inovatif, sehingga dapat berjalan dengan baik sesuai dengan sistem dan norma yang berlaku. Ketersediaan guru yang berkualitas, akan membawa sekolah mencapai tujuan yang telah ditetapkan. Guru adalah salah satu faktor penentu bagi keberhasilan pendidikan di sekolah, karena guru merupakan salah satu sumber pembelajaran yang sangat berarti bagi peserta didik. Di tangan gurulah hasil pembelajaran lebih banyak ditentukan, yaitu pembelajaran yang berkualitas sekaligus bermakna sebagai pemberdaya kemampuan dan kesanggupan peserta didik.

Peran guru dalam pelaksanaan pendidikan merupakan pihak yang sangat berpengaruh dalam proses pendidikan. Guru harus mempunyai pengetahuan yang tinggi agar dalam proses pembelajaran yang terjadi antara guru dan siswa dapat berjalan dengan baik, dapat membawa siswanya kepada tujuan yang hendak dicapai, sesuai dengan perencanaan, menguasai materi yang diajarkan kepada siswa, menggunakan metode yang tepat, mengadakan hubungan yang baik antar individu guru dengan siswa, sesama guru kepala sekolah, tata usaha serta masyarakat sekitarnya, mempunyai pengalaman dan kompetensi, perilaku yang dapat diteladani bagi siswanya, sehingga guru mempunyai wibawa yang baik dalam membangun sekolah yang bermutu. Untuk tercapainya tujuan tersebut dibutuhkan perilaku in-role (organizational citizenship behavior) guru itu sendiri. Peningkatan perilaku in-role tersebut didukung oleh kualitas kehidupan kerja guru dan reward yang diberikan kepada para guru. quality of work life (QWL) yang baik dapat dimiliki guru diiringi dengan pemberian reward yang bisa membangkitkan semangat kerja maka akan memberikan pengaruh positif untuk peningkatan organizational citizenship behavior (OCB).

${ }^{1}$ Staf Pengajar SDIT Attaqwa Babelan Bekasi 
Organizational Citizenship Behavior (OCB) Merupakan perilaku pilihan yang tidak menjadi bagian dari kewajiban kerja formal seorang guru, namun mendukung berfungsinya organisasi tersebut secara efektif. Organizational Citizenship Behavior (OCB) ini juga sering diartikan sebagai perilaku yang melebihi kewajiban formal (extra-role), dan OCB juga merupakan perilaku sosial dari masing-masing individu untuk bekerja melebihi apa yang diharapkan. Perilaku ini cenderung melihat guru sebagai makhluk sosial, dibandingkan sebagai makhluk individu yang mementingkan diri sendiri. Sebagai makhluk sosial, guru mempunyai kemampuan untuk memiliki empati kepada guru lain dan lingkungannya dan menyelaraskan nilai-nilai yang dianutnya dengan nilai-nilai yang dimiliki lingkungannya untuk menjaga dan meningkatkan interaksi sosial yang lebih baik.

Kualitas kehidupan kerja merupakan totalitas pengalaman individu di tempat kerja yang meliputi lingkungan kerja yang aman dan sehat, pekerjaan yang mengembangkan kemampuan individu, menyediakan kesempatan bagi pertumbuhan dan jaminan pribadi, lingkungan sosial yang mendorong identitas pribadi, mobilitas yang tinggi, adanya hak bagi kerahasiaan pribadi dan hak untuk menolak, dan organisasi yang bertanggungjawab secara sosial. Kondisi semua ini memerlukan organizational citizenship behavior (OCB), karena ketika warga organisasi berada dalam lingkungan kerja yang menyenangkan, maka hal itu dapat mendorong kegiatan-kegiatan yang bermanfaat bagi pengembangan organisasi, tanpa memikirkan apakah kegiatan tersebut merupakan tugasnya atau bukan. Dengan demikian warga organisasi bekerja secara sukarela untuk pekerjaan-pekerjaan yang memberikan dampak terhadap kemajuan organisasi. quality of work life (QWL) yang baik dapat dimiliki guru diiringi dengan pemberian reward yang bisa membangkitkan semangat kerja maka akan memberikan pengaruh positif untuk peningkatan organizational citizenship behavior (OCB).

Berdasarkan pemaparan masalah dan pentingnya peranan quality of work life ( $Q W L)$ serta reward terhadap organizational citizenship behavior $(O C B)$ guru. Dengan demikian hasil penelitian ini dapat berguna untuk meningkatkan organizational citizenship behavior $(O C B)$ guru di Babelan, Bekasi.

\section{Organizational Citizenship Behavior (OCB)}

Tentang organizational citizenship behavior (OCB) Robbins dan Mary Coulter (2012:401) mengemukakan bahwa, "organizational citizenship behavior (OCB) is discretionary behavior that's not part of an employee's formal job requirements, but which promotes the effective functioning of the organization." Organizational citizenship behavior (OCB) adalah perilaku sukarela yang bukan merupakan bagian dari persyaratan formal seorang karyawan pada pekerjaannya namun ia tetap meningkatkan fungsi efektif dari organisasi. Brent W. Robert (2002:46) dalam bukunya mengemukakan bahwa, "defined $O C B$ as extra role, discretionary behavior that helps other organization members perform their jobs or that shows support for and conscientiousness toward the organization." Ditetapkan OCB sebagai peran tambahan, perilaku diskresioner yang membantu anggota organisasi lain melakukan pekerjaan mereka atau yang menunjukkan dukungan dan kesadaran terhadap organisasi.

Istilah organizational citizenship behavior (OCB) menurut Greenberg (2003:409) mengemukakan bahwa, "OCB is generally no included as part of any standard performance measures that a company gathers about its employees." OCB umumnya adalah tidak 
termasuk sebagai bagian dari ukuran standar kinerja bahwa sebuah perusahaan dapat memberikan fungsi karyawannya.

Dari beberapa konsep tersebut dapat disintesiskan bahwa organizational citizenship behavior (OCB) adalah perilaku sukarela individu pada pekerjaan yang bukan merupakan bagian dari persyaratan formal untuk meningkatkan fungsi efektif organisasi dengan indikator: (1) altruism (membantu orang lain), (2) conscientiousness (tindakan taat), (3) sportsmanship (sportif), (4) courtesy (menghormati orang lain), (5) civic virtue (tanggung jawab).

\section{Quality of Work Life (QWL)}

Berbicara tentang Quality of Work Life (QWL) Gibson, et, al (2012:370) memberikan penjelasan mengenai definisi QWL Sebagai, "QWL is Management philosophy that enhances employee dignity, introduce cultural change and provide opportunities for growth and development." Definisi ini mereflesikan suatu filosofi manajemen yang berusaha meningkatkan martabat karyawan, memperkenalkan perubahan budaya, dan menyediakan peluang untuk tumbuh dan berkembang. Dalam hal ini,

Sedangkan Mullins (2005:717) mengemukakan konsep QWL adalah "QWL is not new but an approach to the organisation of work and managing people that has evolved over a long period of time. On the Quality of Working Life, people's experiences of work and descriptions of experiments in improving work systems, made recommendations for future government initiatives." QWL ini tidak baru tapi suatu pendekatan terhadap organisasi kerja dan mengelola orang yang telah berkembang selama jangka waktu yang panjang. Terhadap Kualitas kehidupan Bekerja, pengalaman orang-orang kerja dan deskripsi dari pengalaman dalam meningkatkan sistem kerja, membuat rekomendasi untuk inisiatif pemerintah masa depan. Selanjutnya, Ivanka Menken (2009:24) menjelaskan bahwa, "quality of work life (QWL) is the favorableness or unfavorableness of the job environment. The purpose is the develop jobs and working conditions that are excellent for both the employees and the organization" Kualitas Hidup Kerja (QWL) adalah nyaman atau tidaknya lingkungan kerja. Tujuannya adalah mengembangkan pekerjaan dan kondisi kerja yang baik bagi karyawan dan organisasi.

Berdasarkan konsep-konsep yang telah dikemukakan di atas, dapat disintesiskan bahwa Quality of Work Life (QWL) adalah kondisi menyenangkan dan tidak menyenangkan lingkungan pekerjaan atas pengalaman yang dirasakan individu selama di tempat kerja yang mempengaruhi sikap perilakunya dalam bekerja dengan indikator: lingkungan kerja yang sehat, keamanan kerja, Penyelesaian masalah, pengembangan karir, dan partispiasi terhadap organisasi..

\section{Reward}

Reward atau penghargaan merupakan salah satu penguatan dalam mendorong seseorang untuk bekerja lebih giat atau lebih memberikan hasil kerja yang lebih baik. Menurut Fred Luthans (2011:90-100) menyatakan bahwa Reward adalah "organization provide rewards to their personal in order to try to motivate their performance and encourage their loyality and retention. Pay is an unquestionably important form of reward. However, it is not the only way in which organization can reward their people in addition to money, forms of recognition to identify and reward outstanding performance can be a vital, but too often overlooked, part of the organizational reward system. Institusi memberikan penghargaan 
kepada karyawannya untuk memotivasi kinerja mereka dan menolong mereka agar lebih loyal kepada institusi. Gaji adalah bentuk penghargaan yang sangat penting. Namun gaji bukanlah satu-satunya cara organisasi untuk menghargai para karyawannya. Selain uang bentuk-bentuk pengakuan untuk menghargai kinerja optimal merupakan sesuatu yang vital tetapi sering diabaikan.

Selanjutnya Bateman (2009:486) menjelaskan bahwa Reward adalah "there are two types of rewards : (1) extrinsic rewards are given to the people by the boss, the company, or some other person, (2) intrinsic rewards is a reward the person derives directly from performing the job itself. Intrinsic rewards are essential to the motivation underlying creativity. A challenging problem, a chance to create something new, and work that is exciting in and of itself can provide intrinsic motivation that inspire people to devote time and energy to the task." Terdapat dua jenis penghargaan yaitu, (1) penghargaan extrinsik diberikan kepada karyawan oleh pemimpin, perusahaan atau oleh orang lain, sedangkan (2) penghargaan intrinsik adalah penghargaan yang diperoleh langsung dari pelaksanaan pekerjaan itu sendiri. Pengharagaan intrinsik ini penting sebagai pendukung kreativitas. Masalah yang menantang, kesempatan menciptakan sesuatu yang baru serta tugas yang menarik dapat menjadi motivasi instrinsik serta memberikan inspirasi kepada seseorang untuk menggunakan waktu dan tenaganya demi pelaksanaan tugas secara optimal.

Ivancevich (2013:176) menyatakan dalam bukunya bahwa ada beberapa tujuan Reward adalah "the main objectives of reward programs are: (1) to attract qualified people to join the organization. (2) to keep employees coming to work, and (3) to motivate employees to achieve high levels of performance." Tujuan utama dari program reward adalah (1) untuk menarik orang yang memenuhi syarat untuk bergabung dengan organisasi, (2) untuk menjaga karyawan datang bekerja, dan (3) untuk memotivasi karyawan untuk mencapai tingkat kinerja yang tinggi.

Berdasarkan konsep-konsep yang telah di uraikan di atas, dapat disintesiskan reward adalah penghargaan yang diberikan oleh pimpinan/organisasi kepada seseorang yang menunjukkan prestasi kerja yang baik dalam menjalankan tugas pekerjaannya di organisasi tempat bekerja dengan indikator: (1) upah/gaji, (2) tunjangan,(3) penghargaan atas kecakapan, (4) peningkatan pertumbuhan pribadi / promosi dan (5) insentif.

\section{METODE}

Penelitian ini dilakukan di Sekolah Dasar Negeri (SDN) Babelan,Bekasi. Waktu uji coba dilakukan dari Desember 2013 sedangkan waktu penelitian dilakukan bulan Januari 2014. Penelitian ini menggunakan metode penelitian survey dengan pendekatan kuantitatif-kausal, dengan menggunakan analisis jalur (path analysis) Pendekatan ini dipilih untuk menganalisis pola hubungan antar variabel. Alat pengumpulan data pokok dan dokumentasi yang digunakan dalam penelitian ini adalah kuesioner.

Populasi target dalam penelitian ini adalah seluruh guru Sekolah Dasar Negeri (SDN) yang berada di kecamatan Babelan Bekasi. Populasi terjangkaunya adalah Sekolah Dasar Negeri (SDN) yang berada di Desa Babelan Kota yang terdiri dari 9 Sekolah Dasar Negeri (SDN) dengan jumlah guru sebanyak 190 guru yang berada di wilayah Desa Babelan Kota, Babelan Bekasi. Pengambilan sampel dilakukan dengan 
menggunakan teknik sampel acak sederhana (simple random sampling) dengan cara diundi. Sampel yang akan digunakan dalam penelitian ini berjumlah 129 guru.

Sebelum kuesioner digunakan dalam penelitian ini terlebih dahulu dilakukan uji coba untuk menentukan validitas dan reliabitas instrumen. Hasil tersebut digunakan sebagai instrumen untuk mengambil data dalam penelitian di lapangan. Analisis data meliputi: 1) deskripsi data; 2) uji prasyarat analisis normalitas; 3) analisis jalur yang meliputi: analisis model, pengujian hipotesis dan penentuan tingkat pengaruh.

\section{HASIL DAN PEMBAHASAN}

\section{Pengaruh langsung positif Quality of Work Life (QWL) terhadap Organizational} Citizenship Behavior (OCB)

Berdasarkan hasil perhitungan koefisien korelasi sebesar 0,257 dan nilai koefisien jalur sebesar 0,179. Dengan demikian terdapat pengaruh langsung positif Quality of Work Life (QWL) terhadap organizational citizenship behavior. Hasil penelitian tersebut sesuai dengan konsep Kondalkar (2007:314) mengemukakan bahwa, "Quality of Work Life (QWL) is to improve the general working environment of the organization so that the employee enjoy working because they feel pleasant experience interacting with each other." Kualitas Hidup Kerja (QWL) adalah untuk meningkatkan lingkungan kerja umum organisasi sehingga karyawan menikmati bekerja karena mereka merasa pengalaman yang menyenangkan berinteraksi satu sama lain. Untuk organizational citizenship behavior (OCB) Jennifer M. George (2005:92) menyatakan, "organizational citizenship behavior is behavior that is above and beyond the call of duty-that is, behavior that is not required of organizational members but is nonetheless necessary for organizational survival and effectiveness. Organizational citizenship behavior (OCB) adalah perilaku yang melebihi panggilan tugas dimana merupakan perilaku yang tidak diperlukan oleh anggota organisasi tetapi meskipun demikian penting bagi kelangsungan hidup dan efektivitas organisasi.

Adapun teori yang menunjukkan pengaruh Quality of Work Life (QWL) dengan organizational citizenship behavior menurut V.G. Kondalkar (2007:315) dalam bukunya mengatakan bahwa, "QWL, apart from employee point of view, is also considered from organizational point of view that includes factors that measure organizational growth and effectiveness." Dimana dijelaskan bahwa QWL, selain dari sudut pandang karyawan, juga dipertimbangkan dari sudut pandang organisasi yang meliputi faktor-faktor yang mengukur pertumbuhan organisasi dan efektivitas.

Hasil penelitian ini sesuai dengan penelitian yang dilakukan oleh Farideh Haghshenas Kashani (2012:9523), "A high quality of work life (QWL) is essential for all organizations to continue to attract and retain employees. Quality of work life is a comprehensive program which is designated to increase employee satisfaction. The purpose of current study is to survey the relationship between quality of work life and organizational citizenship behavior in Delshad Company." Penelitian ini menjelaskan bahwa sebuah kualitas kehidupan kerja (QWL) yang tinggi adalah penting bagi semua organisasi untuk terus menarik dan mempertahankan karyawan. Kualitas kehidupan kerja adalah program yang komprehensif yang ditujukan untuk meningkatkan kepuasan karyawan dan perilaku kewargaan organisasi di Perusahaan Delshad. Robbins dan Mary Coulter (2012:401) mengemukakan bahwa, "organizational citizenship behavior $(O C B)$ is discretionary behavior 
that's not part of an employee's formal job requirements, but which promotes the effective functioning of the organization." Organizational citizenship behavior (OCB) adalah perilaku sukarela yang bukan merupakan bagian dari persyaratan formal seorang karyawan pada pekerjaannya namun ia tetap meningkatkan fungsi efektif dari organisasi. Brent W. Robert (2002:46) dalam bukunya mengemukakan bahwa, "defined OCB as extra role, discretionary behavior that helps other organization members perform their jobs or that shows support for and conscientiousness toward the organization." OCB sebagai peran tambahan, perilaku diskresioner yang membantu anggota organisasi lain melakukan pekerjaan mereka atau yang menunjukkan dukungan dan kesadaran terhadap organisasi. Dengan demikian, dari penjelasan ini mencerminkan bahwa meningkatnya Quality of Work Life (QWL) pada sebuah organisasi/sekolah maka meningkat pula organizational citizenship behavior guru.

\section{Pengaruh langsung positif Reward terhadap Organizational Citizenship Behavior}

Berdasarkan hasil perhitungan nilai koefisien korelasi sebesar 0,282 dan nilai koefisien jalur sebesar 0,218. Dengan demikian terdapat pengaruh langsung positif Reward terhadap organizational citizenship behavior. Tentang Reward Menurut Richard L Daft (2012:466-467) reward adalah "the rewards informs the persons that the behavior was appropriate and can be used again in the future. Rewards are of two types: intrinsic and extrinsic. Intrinsic rewards are the satisfaction a person receives in the process of performing a particular action. The completion of a complex task may bestow a pleasant feeling of accomplishment, or solving a problem that benefits others may fulfill a personal mission. Extrinsic rewards are given by another person, typically a manager, and include promotions, pay increases, and bonuses." Penghargaan menjadi tanda bagi yang menerima bahwa tindakan yang telah dilakukannya berguna dan boleh diterapkan lagi pada saat-saat mendatang. Terdapat dua macam penghargaan, yaitu intrinsik dan extrinsik. Penghargaan intrinsik adalah kepuasan seseorang yang diperoleh dengan melakukan suatu, misalnya penyelesaian suatu tugas yang sulit ataupun karena melakukan suatu misi menolong orang lain. Penghargaan extrinsik diberikan oleh orang lain, khususnya oleh manajer, misalnya dalam bentuk promosi, kenaikan gaji dan bonus. Sementara organizational citizenship behavior sesuai dengan pendapat Newstroom dan Davis (2007:214) menjelaskan, "organizational citizenship is often marked by its spontaneity, its voluntary nature, its constructive impact on results, its unexpected helpfullness to others, and the fact that it is optional." Organizational citizenship adalah sering ditandai dengan spontanitas, sifat sukarela, dampak membangun terhadap hasil, sikap menolong yang tak terduga kepada orang lain, dan fakta bahwa itu adalah sebuah pilihan.

Hasil penelitian ini mendukung teori McShane (2010:166) bahwa, "money influence an individual's ethical conduct, organizational citizenship, and many other behaviors and attitudes" Uang mempengaruhi perilaku etika individu, kewargaan organisasi, dan banyak perilaku dan sikap lainnya.

Mendukung teori tersebut Stephen P. Robbins (2005:28) memberikan penjelasan mengenai pengaruh reward terhadap OCB yaitu, "If organizations actually rewarded individuals for performance rather than according to criteria such as seniority, effort, skill level, 
and job difficulty, then the theory's validity might be considerably greater. Rather than invalidating expectancy theory, this criticism can be used in support of the theory, because it explains why a significant segment of the workforce exerts low levels of effort in carrying out job responsibilities." Dikatakan bahwa jika organisasi benar-benar dihargai individu untuk kinerja daripada menurut kriteria seperti senioritas, upaya, tingkat keterampilan, dan kesulitan pekerjaan, maka validitas teori ini mungkin jauh lebih besar. Daripada membatalkan teori harapan, kritik ini dapat digunakan untuk mendukung teori ini, karena menjelaskan mengapa segmen yang signifikan dari angkatan kerja diberikan rendahnya tingkat upaya dalam melaksanakan tanggung jawab pekerjaan. Bateman (2009:486) menjelaskan bahwa Reward adalah "there are two types of rewards : (1) extrinsic rewards are given to the people by the boss, the company, or some other person, (2) intrinsic rewards is a reward the person derives directly from performing the job itself. Intrinsic rewards are essential to the motivation underlying creativity. A challenging problem, a chance to create something new, and work that is exciting in and of itself can provide intrinsic motivation that inspire people to devote time and energy to the task." Terdapat dua jenis penghargaan yaitu, (1) penghargaan extrinsik diberikan kepada karyawan oleh pemimpin, perusahaan atau oleh orang lain, sedangkan (2) penghargaan intrinsik adalah penghargaan yang diperoleh langsung dari pelaksanaan pekerjaan itu sendiri. Pengharagaan intrinsik ini penting sebagai pendukung kreativitas. Masalah yang menantang, kesempatan menciptakan sesuatu yang baru serta tugas yang menarik dapat menjadi motivasi instrinsik serta memberikan inspirasi kepada seseorang untuk menggunakan waktu dan tenaganya demi pelaksanaan tugas secara optimal. Hal ini mencerminkan peningkatan reward yang dirasakan guru, maka akan menigkatan Organizational Citizenship Behavior $(O C B)$. 


\section{Pengaruh langsung positif Quality of Work Life (QWL) terhadap Reward}

Berdasarkan hasil perhitungan nilai koefisien korelasi sebesar 0,357 dan nilai koefisien jalur sebesar 0,357. Dengan demikian terdapat pengaruh langsung positif Quality of Work Life (QWL) terhadap reward. Mengenai Quality of Work Life (QWL), Ivanka Menken (2009:24) menjelaskan bahwa, "quality of work life (QWL) is the favorableness or unfavorableness of the job environment. The purpose is the develop jobs and working conditions that are excellent for both the employees and the organization." Dapat diartikan bahwa Kualitas Hidup Kerja (QWL) adalah nyaman atau tidaknya lingkungan kerja. Tujuannya adalah mengembangkan pekerjaan dan kondisi kerja yang baik bagi karyawan dan organisasi. Sementara tentang reward Kreitner dan Kinicky (2010:255) menjelaskan bahwa Reward adalah "rewards are an ever-present and always controversial feature of organizational life." Penghargaan adalah fitur selalu hadir dan selalu kontroversial dalam kehidupan organisasi.

Adapun teori yang menunjukkan pengaruh Quality of Work Life (QWL) terhadap reward Linda K. Stroh et.al (2002:443)mengemukakan bahwa, "QWL programs typically emphasize the importance of workers rights and industrial democracy. Program objectives often include increasing job security, instituting reward systems, and expanding the opportunities for growth and workplace participation." Dimana ditunjukkan bahwa program QWL biasanya menekankan pentingnya hak-hak pekerja dan demokrasi industri. Tujuan program sering termasuk meningkatkan keamanan kerja, melembagakan sistem penghargaan, dan memperluas kesempatan untuk pertumbuhan dan partisipasi kerja. Mullins (2005:717) mengemukakan konsep QWL adalah "QWL is not new but an approach to the organisation of work and managing people that has evolved over a long period of time. On the Quality of Working Life, people's experiences of work and descriptions of experiments in improving work systems, made recommendations for future government initiatives." QWL ini tidak baru tapi suatu pendekatan terhadap organisasi kerja dan mengelola orang yang telah berkembang selama jangka waktu yang panjang. Terhadap Kualitas kehidupan Bekerja, pengalaman orang-orang kerja dan deskripsi dari pengalaman dalam meningkatkan sistem kerja, membuat rekomendasi untuk inisiatif pemerintah masa depan. Selanjutnya, Ivanka Menken (2009:24) menjelaskan bahwa, "quality of work life $(Q W L)$ is the favorableness or unfavorableness of the job environment. The purpose is the develop jobs and working conditions that are excellent for both the employees and the organization" Kualitas Hidup Kerja (QWL) adalah nyaman atau tidaknya lingkungan kerja. Hal ini mencerminkan bahwa peningkatan Quality of Work Life (QWL), maka akan mengakibatkan ketepatan reward yang diberikan organisasi/sekolah kepada guru. 


\section{PENUTUP}

Kesimpulan: Berdasarkan hasil penelitian ini dapat disimpulkan bahwa : (1) Terdapat pengaruh positif quality of work life (QWL) terhadap organizational citizenship behavior yang ditentukan oleh derajat besarnya pengaruh dalam bentuk koefisien korelasi dan koefisien jalur. Selanjutnya dapat diketahui signifikansi pengaruh antara quality of work life (QWL) terhadap organizational citizenship behavior secara parsial. Hal ini memiliki makna dan penegasan bahwa quality of work life (QWL) secara empiris bukan satusatunya variabel prediktor bagi varians skor organizational citizenship behavior. (2) Terdapat pengaruh positif reward terhadap organizational citizenship behavior yang ditentukan oleh derajat besarnya pengaruh dalam bentuk koefisien korelasi dan koefisien jalur. Selanjutnya dapat diketahui signifikansi pengaruh antara reward terhadap organizational citizenship behavior secara parsial. Hal ini memiliki makna dan penegasan bahwa reward secara empiris bukan satu-satunya variabel prediktor bagi varians skor organizational citizenship behavior. (3) Terdapat pengaruh positif quality of work life $(\mathrm{QWL})$ terhadap reward yang ditentukan oleh derajat besarnya pengaruh dalam bentuk koefisien korelasi dan koefisien jalur. Selanjutnya dapat diketahui signifikansi pengaruh antara quality of work life (QWL) terhadap reward secara parsial. Hal ini memiliki makna dan penegasan bahwa quality of work life ( $Q W L)$ secara empiris bukan satu-satunya variabel prediktor bagi varians skor reward.

Saran: Beberapa hal yang disarankan dalam penelitian ini adalah sebagai berikut: (1) Bagi kepala sekolah di Babelan Bekasi, agar dapat melaksanakan kegiatan-kegiatan untuk pengembangan empat kompetensi guru yaitu kompetensi kepribadian, pedagogik, professional, dan sosial, baik melalui pendidikan dan pelatihan guru, serta mampu mengembangkan sumber daya yang ada dalam lingkup lembaga yang dipimpinnya. (2) Bagi guru Sekolah Dasar Negeri (SDN) Babelan Bekasi, agar dapat meningkatkan kompetensi atau professionalismenya sehingga pemberian reward dapat sesuai dengan perilaku kerja yang baik yang telah dilakukannya. Dalam hal ini, guru tidak hanya menuntut sekolah untuk memberikan reward, akan tetapi juga mau dan mampu meningkatkan perilaku kerja yang baik sehingga pantas diberikan reward yang sesuai dengan hasil kerjanya dan mendukung setiap program yang telah ditetapkan oleh lembaga.(3) Hasil penelitian tentang organizational citizenship behavior (OCB) guru memerlukan penelitian lebih lanjut. Penelitian selanjutnya diharapkan dapat mengungkap faktor-faktor lain yang mempengaruhi organizational citizenship behavior $(O C B)$ guru selain quality of work life (QWL) dan reward. Disamping itu perlu juga dilakukan penelitian untuk mengemukakan pendekatan atau cara praktis peningkatan organizational citizenship behavior $(O C B)$ guru. 


\section{DAFTAR RUJUKAN}

Bateman, Thomas S. dan Scott S. Snell, Management Leading \& Collaborating in a Competitive World. New York: McGraw-Hill / Irwin. 2009.

Daft, Richard L,. New Era of Management. Canada : South-Western Cengage Learning, 2012.

George, Jennifer M. and Gareth R. Jones. Understanding and Managing Organizational Behavior: New Jersey, Prentice Hall, 2005

Gibson, Ivancevich, Denelly, Konopaske. Organizations Behaviors, structure, process. International edition. Singapore: McGraw-Hill, 2012.

Greenberg, Jerald, Robert A. Baron. Behavior in Organizations. Ninth Edition. New Jersey: Pearson Prentice Hall, 2003.

Ivancevich, John M., Human Resource management. New York: MCGraw-Hill, 2013.

Kashani, Farideh Haghshenas, "A Review on Relationship between Quality of Work Life and Organizational Citizenship Behavior (Case Study: An Iranian Company)", J. Basic. Appl. Sci. Res., 2(9)9523-9531, 2012, Journal of Basic and Applied Scientific Research

Kondalkar, V.G. Organizational Behavior. New Delhi: New Age International Publishers, 2007.

Kreitner, Robert dan Angelo Kinicky, Organizational Behavior. New York: Mc Graw Hill, 2010.

Luthans, Fred,. Organizational Behavior. Boston: McGraw Hill, 2011.

McShane Steven L, Marry ann Von Glinov. Organizational Behavior. United States: McGraw-Hill, 2010.

Menken, Ivanka. Organizational behavior and leadership management essentials. Emereo: Publishing, 2009.

Mullins, Laure J., Management and Organizational behavior, Seventh Edition. England: Prentice Hall, 2005.

Newstroom, John W.,Keith Davis. Organizational Behavior human behavior at work. International Edition. New York: McGraw-Hill, 2007.

Robbins, Stephen P. Organizational Citizenship Behavior, Eleventh Edition, New Jersey: Pearson Prentice Hall, 2005.

Robbins, Stephen P. and Mary Coulter. Management. England: Pearson Education, 2012. 
Roberts, Brent W., and Robert Hogan. Personality Psychology in the workplace, American Psychological Association, 2002.

Stroh, Linda K. Gregory B. Northcraft, Margaret A. Neale, Organizational Behavior A Management Challenge. New Jersey: Lawrence Erlbaum Associates, Inc, 2002. 